\title{
ACUTE RESPIRATORY VIRAL INFECTIONS IN CHILDREN IN RIO DE JANEIRO AND TERESÓPOLIS, BRAZIL
}

Maria Carolina M. ALBUQUERQUE(1), Rafael B. VARELLA(2) \& Norma SANTOS(1)

\begin{abstract}
SUMMARY
The frequency of viral pathogens causing respiratory infections in children in the cities of Rio de Janeiro and Teresópolis was investigated. Nasal swabs from children with acute respiratory illnesses were collected between March 2006 and October 2007. Specimens were tested for viral detection by conventional (RT)-PCR and/or real time PCR. Of the 205 nasal swabs tested, 64 (31.2\%) were positive for at least one of the viral pathogens. Single infections were detected in 56 samples, 50 of those were caused by RNA viruses: 33 samples tested positive for rhinovirus, five for influenza A, five for metapneumovirus, four for coronavirus and, three for respiratory syncytial virus. For the DNA viruses, five samples were positive for bocavirus and one for adenovirus. Co-infections with these viruses were detected in eight samples. Our data demonstrate a high frequency of viral respiratory infections, emphasizing the need for a more accurate diagnosis particularly for the emerging respiratory viruses. The fact that the emerging respiratory viruses were present in $9.2 \%$ of the tested samples suggests that these viruses could be important respiratory pathogens in the country.
\end{abstract}

KEYWORDS: Respiratory infection; Viral infection; Viral diagnosis.

\section{INTRODUCTION}

Acute respiratory infections represent a major cause of human disease and one of the most important causes of child mortality throughout the world ${ }^{30,46}$. Although there are considerable variations in infantile mortality, the World Health Organization has classified the infections of the lower respiratory tract as the second most important cause of death among children under five years of age.

Viral respiratory diseases are among the most common illnesses affecting children and adults ${ }^{52}$. The respiratory tract can be infected by RNA and DNA viruses, which induces several clinical syndromes. The human respiratory syncytial virus (HRSV), human parainfluenza virus (HPIV), influenza A virus (FLUAV) and influenza B virus (FLUBV), human adenovirus (HAdV), human coronavirus (HCoV), and human rhinovirus (HRV) are recognized as agents of human respiratory disease. Several other viruses, such as human metapneumovirus (HMPV), human bocavirus (HBoV), and the newly discovered human coronaviruses HCoV-NL63 and HCoV-HKU1, have been identified as potential respiratory pathogens $\mathrm{s}^{30,46}$. In addition, two new human polyomaviruses ( HPyV), KIPyV and WUPyV, have been detected in patients with respiratory infections.

The main goal of this study was to identify the frequency of viral pathogens causing respiratory infections in children with respiratory illness in the cities of Rio de Janeiro and Teresópolis.

\section{MATERIAL AND METHODS}

Sample Collection: Nasal swabs from 205 children (median age 3.3 years; range one month to 15 years) with both upper and lower acute respiratory illnesses were collected between March 2006 and October 2007 and tested for viral pathogens. The nasal swabs were immersed in $1 \mathrm{~mL}$ of virus transport media and kept at $-70{ }^{\circ} \mathrm{C}$ until processing. Acute respiratory illness was defined by the presence of rhinorrhea and/or cough and/or respiratory distress and/or sore throat, associated or not to fever, with maximal duration of seven days. The specimens were collected from hospitalized patients, emergency departments and walk-in clinics at two university hospitals in the cities of Rio de Janeiro (137 samples) and Teresópolis (68 samples). Relevant clinical information, including hospitalization status, age, sex, and clinical symptoms, was collected during the first medical visit by means of a standard questionnaire.

The study protocol was reviewed and approved by the Ethics Committees in Research of the Instituto de Puericultura e Pediatria Martagão Gesteira of the Universidade Federal do Rio de Janeiro and Fundação Educacional Serra dos Órgãos, of the Centro Universitário Serra dos Órgãos. The parents of all children involved in the study had given informed consent, in accordance with Resolution 196/96, of the Brazilian Ministry of Health.

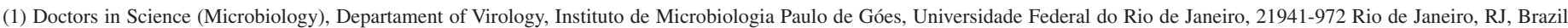
E-mails: nsantos@micro.ufrj.br; mcmalbuquerque@gmail.com

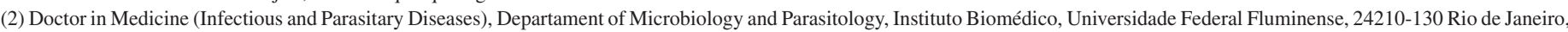
RJ, Brazil. E-mail: rvarella@id.uff.br

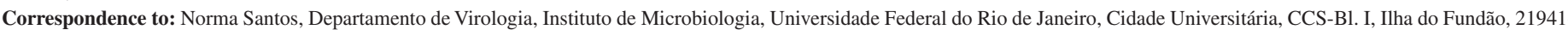
590 Rio de Janeiro, RJ, Brasil. Phone: 5521 2560-8344 ext. 165, Fax: 5521 2560-8028. E-mail: nsantos@micro.ufrj.br 
ALBUQUERQUE, M.C.M.; VARELLA, R.B. \& SANTOS, N. - Acute respiratory viral infections in children in Rio de Janeiro and Teresópolis, Brazil. Rev. Inst. Med. Trop. Sao Paulo, 54(5): 249-55, 2012.

Nucleic acid extraction: Nucleic acid was extracted from $200 \mu \mathrm{L}$ of the sample by using Wizard® Genomic DNA Purification KIT (Promega, Madison, WI, USA) or RNAgents ${ }^{\circledR}$ kit (Promega) according to the manufacturer's instructions.

Viral detection: Specimens were tested for presence of FLUAV and $\mathrm{FLUBV}^{48}, \mathrm{HRSV}^{48}, \mathrm{HPIV}^{1}, \mathrm{HAdV}^{4}, \mathrm{HRV}^{34}, \mathrm{HMPV}^{32}, \mathrm{HBoV}^{45}$, $\mathrm{WUPyV}^{28}$, and $\mathrm{KIPyV}^{3}$ by conventional PCR and (RT)-PCR assays as previously described. A real time PCR protocol was used for detection of HCoVs (229E, OC43, NL63 and HKU1) ${ }^{18,57}$. All assays were included positive and negative external controls. Conventional PCR and RT-PCR were performed in a Veriti 96 well (Applied Biosystems, Foster City, CA, USA) thermocycler and the amplified products were detected by agarose gel electrophoresis and staining with ethidium bromide. Realtime RT-PCR was performed in an ABI StepOne Real-time PCR System (Applied Biosystems).

\section{RESULTS}

Patient demographics: Among the 205 samples, 73 (35.6\%) were collected from hospitalized patients (inpatients) and 132 from outpatients children (59 [28.8\%] from the emergence department and 73 [35.6\%] from the walk-in clinics). Only one specimen was obtained per patient. The age distribution of the subjects was as follow: $95(46.3 \%)$ were < one year of age; $61(29.8 \%)$ were between 1.1 - 5 years; $30(14.6 \%)$ were between 5.1 - 10 years; $16(7.8 \%)$ between 10.1 - 15 years; and for three patients the age was not informed. The most common symptoms observed among the patients were a cough $(54 \% ; 111 / 205)$, fever $(53.6 \%$; $110 / 205)$, rhinorrhea $(47.8 \%$; 98/205), nasal congestion $(27.3 \% ; 56 / 205)$, pneumonia $(24.4 \%$; 50/205), wheezing $(23.4 \%$; 48/205), bronchitis/ bronchiolitis $(18 \% ; 37 / 205)$, broncospasm $(8.3 \%$; 17/205), asthma $(5.9 \%$; 12/205) and diarrhea (4.4\%; 9/205). Few patients presented headache, sore throat, tonsillitis, exanthema, laryngomalacia, vomit or otitis.

Virus detected: A total of $64(31.2 \% ; \mathrm{n}=205)$ samples were positive for at least one of the viral pathogens specified above: 42 positive samples from the city of Rio de Janeiro (30.7\%; 42/137) and 22 from Teresópolis $(32.4 \%$; 22/68). RNA viruses were detected in higher frequency than DNA virus. Thirty-three single infections were detected with HRV, five with FLUAV, five with HMPV, five with $\mathrm{HBoV}$, three with HRSV, three with HCoV-HKU1 or -NL63 one with HCoV-OC43, and one with HAdV. Co-infections with these viruses were observed in eight samples including two samples positive for KIPyV and WUPyV and HPIV was not detected (Table 1).

Seasonality: The majority of viral infections $(79.7 \%$; $51 / 64)$ was detected between June and November (late autumn through spring months) (Fig. 1). Yet, positive samples were detected all year round except for the months of February and May.

Virus detection $\mathbf{x}$ patient status: Among patients positive for viral pathogen $14(22 \%$; 14/64) were inpatients (hospitalized) at the time of samples collection; while $18(28 \%$; 18/64) patients attended the emergency department and $32(50 \% ; 32 / 64)$ the walk-in clinics.

The age of the patients infected with viruses ranged from three months to 15 years (median 3.3 years); 50\% (32/64) of the patients positive for viral infections were under one year of age; $25 \%(16 / 64)$
Table 1

Respiratory viruses detected in the study

\begin{tabular}{lc}
\hline Virus detected & $\begin{array}{c}\text { Number of positive } \\
\text { samples }\end{array}$ \\
\hline FLUAV & 5 \\
HRSV & 3 \\
HMPV & 5 \\
HRV & 33 \\
HCoV-NL63 & 2 \\
HCoV-HKU1 & 1 \\
HCoV-OC43 & 1 \\
HAdV & 1 \\
HBoV & 5 \\
HCoV-NL63 + HMPV & 1 \\
HCoV-NL63 + HRV & 1 \\
HMPV + HRV + HCoV-OC43 + HAdV & 1 \\
HMPV + KIPyV & 1 \\
HBoV + HRV & 1 \\
HBoV + WUPyV & $\mathbf{6 4}$ \\
FLUAV + HRV + HCoV-OC43 & 1 \\
HRSV+HCoV-OC43 & 1 \\
Total & 1 \\
\hline & 1 \\
\hline
\end{tabular}

${ }^{\dagger} \mathrm{FLUBV}$ and HPIV were not detected.

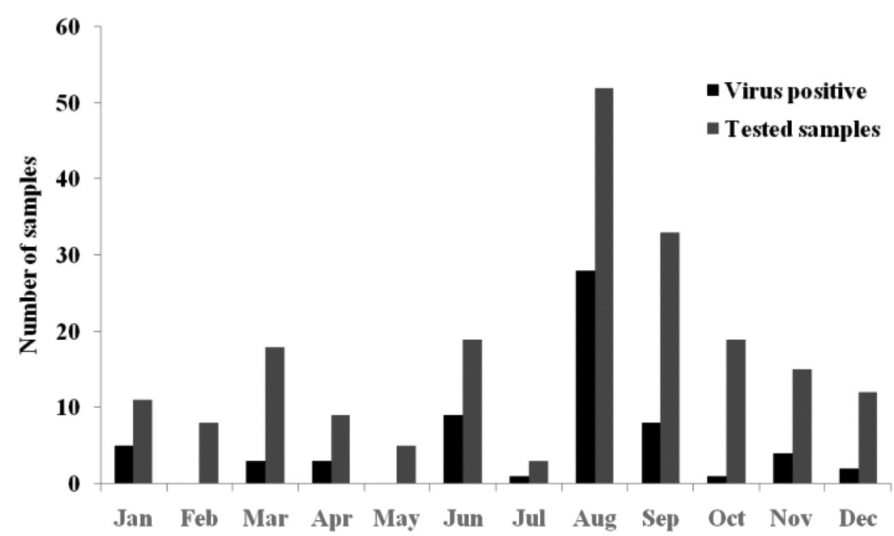

Fig. 1 - Monthly distribution of acute respiratory viral infections in children in Rio de Janeiro and Teresópolis between March 2006 and October 2007.

were between 1.1 - 5 years of age; $17.2 \%$ (11/64) were between 5.1 - 10 years; three patients were over 10.1 years of age. For two patients the ages were not informed.

Virus detected $\mathbf{x}$ patient symptoms: The symptoms most frequent observed among patients with HRV single infections were cough $(67 \%)$, rhinorrhea $(67 \%)$ and fever $(52 \%)$. The age ranged from one month 
to 12 years. Most patients were treated at the walk-in clinics. Of the four patients with co-infections involving $\mathrm{HRV}(\mathrm{HRV}+\mathrm{HMPV}+\mathrm{HCoV}-$ OC43+HAdV; HRV+HCoV-NL63; HRV+HBoV; HRV+FLUAV) three were also treated at the walk-in clinics and one attended the emergency department.

Patients only infected with FLUAV were older (between 1 - 15 years of age - three of them were between nine and 15 years of age). Two out of five influenza-positive patients were hospitalized; the most frequent symptoms presented were rhinorrhea (80\%), nasal congestion $(60 \%)$, cough and fever (40\% each). One patient was co-infected with FLUAV + HRV.

Patients with HMPV infections had a myriad of symptoms, including fever, cough, rhinorrhea, wheezing, and sore throat. Of the five patients with single infections, four were treated at walk-in clinics and one was treated at an emergency department. A patient co-infected with HMPV and HCoV-NL63 was treated at a walk-in clinic, and a patient co-infected with HMPV and KIPyV and one co-infected with HMPV, HCoV-OC43, HAdV, and HRV were treated at an emergency department. The patient co-infected with KIPyV was a 4-year-old boy with cough, fever, rhinorrhea, and wheezing.

$\mathrm{HBoV}$ was detected in samples from five patients as a single infection and in samples from two patients as a co-infection with HRV or WUPyV. Three patients had pneumonia (two single infections and one co-infection with HRV). Two of the three were treated at walk-in clinics; one of the patients with only $\mathrm{HBoV}$ infection was hospitalized. The patient coinfected with WUPyV was a 10-month-old boy who had been treated at an emergency department after exhibiting cough, rhinorrhea, and laryngomalacia.

HRSV was only detected among children younger than one year of age treated at an emergency department. Patients presented rhinorrea, fever, cough and nasal congestion. One patient was co-infected with $\mathrm{HCoV}-\mathrm{OC} 43$.

The diagnosis for most patients infected with HCoV-NL63 or HCoVHKU1 was pneumonia. Of the three patients with single infections, two were hospitalized and one was treated at the emergency department; the two patients with mixed infection of HCoV-NL63 and HMPV or HRV were treated at walk-in clinics. The patient positive for HCoV-OC43 was a three-month-old child who was hospitalized with bronchiolitis.

A five-year-old child positive for HAdV presented fever, wheezing and nasal congestion and was treated at the walk-in clinic.

\section{DISCUSSION}

Viral infection is a major cause of respiratory illness among children. The majority of these infections are caused by HRSV, FLUAV and FLUBV, HPIV and HAdV ${ }^{45}$. Newly discovered viruses such as HMPV, HBoV, HCoV-NL63 and HCoV-HKU1, have also been demonstrated to be important respiratory pathogens ${ }^{26,39}$. Moreover, two new human polyomaviruses (KIPyV and WUPyV) are been described among patients with respiratory infections ${ }^{26,39}$.

In Brazil, epidemiological studies have demonstrated the importance of viruses as etiological agents of respiratory disease $5,7,8,10,14,16,17,19,25,29,33,35,38,40,43,51,53,59,60$. However, because such studies are mostly focused on the most common respiratory pathogens (FLUAV, HRSV, HPIV, HRV and HAdV), the role of emerging viruses as etiological agents of respiratory disease among Brazilian children remains unknown.

Generally, RNA viruses, particularly HRSV, FLUAV and HRV, are more often associated to respiratory infections than DNA viruses ${ }^{30,46}$. In the present study infections caused by RNA viruses represented $89 \%$ $(57 / 64)$ of the positive samples while DNA viruses (HAdV, HBoV and $\mathrm{HPyV})$ were detected in $15.6 \%$ (10/64) of the samples, including mixed infections.

Among the RNA viruses, HRSV is usually the pathogen more often detected in children with acute respiratory disease hospitalized or not $^{7,11,13,14,33,37,51,53}$. Yet, HRV was the most common virus detected in our study $(57.8 \%$; 37/64, including co-infections). One possible explanation for these findings could be the fact that HRV is predominantly found in upper respiratory tract infection, with high levels of viral concentration in nasal secretions ${ }^{55}$ and, material of choice in our study as nasal swabs. On the other hand, HRSV is detected in higher concentration in secretion from the lower respiratory tract. Still, other studies using nasal swabs or nasopharyngeal aspirate from hospitalized and non-hospitalized patients also showed a predominance of $\mathrm{HRV}^{8,12,44,60}$. In the city of Fortaleza, Brazil, an epidemiological surveillance carried out during 29 months showed a high incidence of respiratory illness and a predominance of infections caused by HRV $(45.6 \%)^{5}$. Other studies in the country also demonstrated a predominance of HRV. In a longitudinal study among children in daycare centers in Salvador, Bahia, SOUZA et al. showed a high prevalence $(48.3 \%)$ of HRV infections ${ }^{47}$. In another study performed in Salvador by NASCIMENTO-CARVALHO et al. HRV was the most common viral pathogen $(21 \%)$, detected in the same proportion as Streptococcus pneumonia ${ }^{36}$. BELLEI et al. evaluated the frequency of viral infections among healthcare workers in São Paulo and showed a predominance of HRV $(37.7 \%)^{6}$. BONFIM et al. studies on the frequency of respiratory pathogens in children attending daycare centers in São José do Rio Preto, São Paulo, between 2003 and 2005, also showed the predominance of HRV $(37.7 \%)^{8}$.

Similar to other respiratory pathogens, HRV seasonality varies geographically due to temperature variations. In the temperate areas of the north hemisphere one peak of infections occurs in September (autumn) and a second peak occurs in April/May (spring). In the temperate areas of the south hemisphere, the seasonal incidence of these infections is similar to that seen at the north hemisphere ${ }^{55}$. In Brazil, a study in Salvador showed a peak of infection by HRV during the autumn ${ }^{47}$. Another study in São José do Rio Preto found that HRV was detected more frequently in autumn, but the virus occurred throughout the study, with low frequency in the summer months (December, January and, February) ${ }^{8}$. In our study, carried out at Rio de Janeiro and Teresópolis, we detected a peak of HRV infection during the late autumn/winter and early of spring as 30 out of $33 \mathrm{HRV}$-positive single infections were detected between June and September with the highest peak in August (45.5\%; 15/33).

Many studies have suggested an association between HRV infections and exacerbation of asthma ${ }^{31,55}$. Twelve patients participating in our study presented symptoms of asthma at the time of sample collection. Four of 


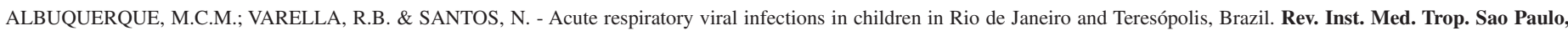
54(5): 249-55, 2012.

those individuals were positive for HRV infection. However, we could not draw a conclusion because the number of patients with asthma was small.

FLUAV was only detected in $9.4 \%(6 / 64)$ of the samples. During a surveillance done in São Paulo, in 2007, THOMAZELLI et al. detected FLUAV in $5 \%$ of the samples ${ }^{51}$. Another study in the same state performed between 2003 and 2005 detected FLUAV and FLUBV in $23.8 \%$ of the samples $^{8}$. In Curitiba, this virus was responsible for $8.3 \%$ of infections among pediatric and transplant patients ${ }^{51}$. In Minas Gerais FLUAV and FLUBV were detected in $9.5 \%$ of samples collected from children younger than five years of age ${ }^{15}$. In Brazil, the flu vaccine program began in 1999 and since then the vaccine has been distributed off charge for children and elderly over 60 years of age, healthcare workers and incarcerate population. Surveillance studies carried out in São Paulo and Minas Gerais indicate that the vaccine coverage reached between $63 \%$ and $66 \%$ of the target population ${ }^{15,22,26}$. This fact could explain the low frequency of FLUV infections found in the country recently.

Generally the epidemiological studies performed in Brazil show a high frequency of infection by HRSV ${ }^{8,14,33,37,42,49-51}$. Differently, we only detect four $(6.3 \%$; 4/64) HRSV infections. Nevertheless, the above mentioned studies were done in subtropical areas of the country such as São Paulo ${ }^{33,37,51}$, Porto Alegre ${ }^{49,50}$ and Minas Gerais ${ }^{14}$ where the average temperature is below $18^{\circ} \mathrm{C}$, with a thermal amplitude between $9{ }^{\circ} \mathrm{C}$ and $13^{\circ} \mathrm{C}$, whereas the state of Rio de Janeiro is a more tropical area with the average temperature between $18{ }^{\circ} \mathrm{C}$ and $22{ }^{\circ} \mathrm{C}$ and a thermal amplitude between $7{ }^{\circ} \mathrm{C}$ and $9{ }^{\circ} \mathrm{C}$. Perhaps this thermal variation could explain the low frequency of HRSV found in our study, since other surveillance done in northern Brazil, a tropical area where the average temperature exceed $20{ }^{\circ} \mathrm{C}$, the $\mathrm{HRV}$ is more prevalent than $\mathrm{HRSV}^{5,36,47}$. Corroborating this theory, a study in Wales between 1991 and 2004, demonstrated that a rise of $1{ }^{\circ} \mathrm{C}$ in the annual temperature average during this period shortened the HRSV season in 3.1 weeks $^{21}$. On the other hand, a recent study performed in the city of Recife, northeast Brazil, found an incidence of HRSV infection of $37 \%$ testing nasopharyngeal aspirates of children less than five years of age ${ }^{7}$.

In Brazil, the frequency of HAdV infections usually varies between $2.3 \%$ and $9.9 \%^{2,5,14,33,49-51}$. We found a frequency of $3.1 \%(2 / 64)$ of HAdV.

The HPIV presents a distinct seasonal pattern, with a biannual epidemic pattern, particularly for HPIV-1, 2 and, $3^{61}$. We did not detect any sample positive for HIPV. It seems that, depending on the region studied, season and size of the study population, this virus may not present a significant prevalence. In Fortaleza, Ceará, a study carried out between 2001 and 2006, 3070 nasopharyngeal aspirates were analyzed and $976(31.8 \%)$ were positive for viral infection. Nevertheless, only $3.8 \%$ tested positive for HPIV ${ }^{25}$. In São Paulo, THOMAZELLI et al. analyzed 336 respiratory samples and found $28(8.3 \%)$ to be positive for HPIV-3 and two $(0.6 \%)$ for HPIV-1 ${ }^{51}$. In Uberlândia, Minas Gerais, HIPV was detected in $6.3 \%$ of the 379 samples tested ${ }^{14}$. In Porto Alegre, Rio Grande do Sul, STRALIOTTO et al. found only $2.3 \%$ positivity for HPIV in samples collected in 1996 and $1.5 \%$ in samples from 1990-1992 ${ }^{49,50}$. In São José do Rio Preto, BONFIM et al. found HIPV in 2.4\% (19/782) samples collected between 2003 and $2005^{8}$.

The literature indicates that $20 \%$ to $60 \%$ of confirmed cases of pneumonia the pathogen cannot be identified. The published data have also showed that viral pneumonia are more frequent than bacterial pneumonia, especially among < 2-year-old children ${ }^{24}$. Yet, only in $40 \%$ of those cases a viral agent is identified, even when highly sensitive molecular tests are applied ${ }^{30,46}$. It suggests that unknown viruses could be circulating among the population. Since 2001, new viruses are being identified and the epidemiology has demonstrated that some of those could be associated to respiratory illnesses ${ }^{30,46}$.

The HMPV was first described in 2001 and since then has been frequently detected in association to respiratory infections ${ }^{30,46}$. We found that $12.5 \%$ (8/64) of our samples were positive for HMPV: five patients had single infections (mean age 2.2 years old, range six months-five years old) and three patients presented mixed infections (Table 1); none of them were hospitalized but one patient with single infection attended the emergency department presenting lower respiratory tract symptoms. DEBURet al. performed a retrospective study in Curitiba, Paraná, and analyzed nasopharyngeal aspirates from 1,572 individuals collected between 2006 and 2008. They found HMPV in $3.9 \%$ of the samples. The incidence was higher in outpatients $(5.9 \%$; $\mathrm{n}=493)$, whose mean age was 19.7 years (range six months-75 years old), than in inpatients $(3 \% ; \mathrm{n}=1079)$, whose mean age was 7.6 months (range one month-26 years old). The outpatients had upper respiratory tract infections with flu-like symptoms and all hospitalized children had lower respiratory tract infections ${ }^{19}$. Other studies have shown a significant positivity for HMPV in Brazil as well $7,8,16,20,38,40,51,59,60$.

$\mathrm{HBoV}$ is another emergent virus associated to illness of the respiratory tract. It was first described in 2005 and has been detected in $1.5 \%$ to $19 \%$ of patients with acute respiratory infection ${ }^{30,46}$. In this study we detected $\mathrm{HBoV}$ in $10.5 \%(7 / 64)$ of the samples. Other studies have found similar rates in Brazil $1^{7,27,40}$.

Prior to 2003 there were only two coronavirus species known to infected human, the HCoV-OC43 and the HCoV-229E. In 2005 three new $\mathrm{HCoV}$ species were recognized as human pathogens: SARS-CoV, $\mathrm{HCoV}-\mathrm{NL} 63$ and HCoV-HKU ${ }^{30}$. The SARS-CoV caused a pandemic in 2002 but has not been detected in the human population since $2004^{30}$. The HCoV-NL63 has been detected in 1\%-10\% of children with respiratory infection and has been associated to pneumonia ${ }^{41}$. The HCoV-HKU1 has been detected in $0.3 \%$ to $2.4 \%$ of individuals with respiratory disease $\mathrm{e}^{23,62}$. We found eight samples positive for $\mathrm{HCoV}$ being one sample positive for HCoV-HKU1, four positive for HCoV-NL63 and three for HCoVOC43. Three HCoV-NL63-positive patients presented pneumonia. Patients infected with HCoV-HKU1 usually present rhinorrhea, cough, wheezing, fever, bronchiolitis or pneumonia ${ }^{46}$. The patient positive for HCoV-HKU1 was a 4-month-old child who presented fever, bronchiolitis, nasal congestion and wheezing. Generally, the $\mathrm{HCoV}$ OC43 causes common cold, although it has already been described in cases of severe infection of the lower respiratory tract. Rhinorrea and bronchiolitis were the most frequent symptoms associated to $\mathrm{HCoV}$ OC43 in our study; two patients were under six months of age. Few cases of the emerging $\mathrm{HCoV}$ in Brazil were described. GÓES et al. did a retrospective analysis of nasopharyngeal aspirate samples collected from children in 1995 and detected six $(3.6 \%$; $n=169)$ cases of $\mathrm{HCoV}$ HKU1 infections. The positive samples were associated with pertussis, pneumonia, bronchiolitis, and diarrhe ${ }^{29}$. More recently, CABEÇA \& BELLEI described a case of HCov-NL63 infection in a hospitalized patient suspected of influenza virus H1N1 2009 infection. The patient was 
a 46-year-old female with diabetes presenting influenza-like symptoms that progressed to hemorrhagic pneumonia, respiratory and renal failure, brain edema and death ${ }^{10}$.

Recently two new polyomaviruses, KIPyV and WUPyV, were detected in respiratory samples ${ }^{3,28}$. Currently these agents have been described in different countries throughout the world ${ }^{9,56}$ suggesting a global distribution. In our study, these viruses were only detected in co-infections (WUPyV+HBoV and KIPyV+HMPV). Interestingly, a significant high rate of co-infection with other respiratory viruses (up to $80 \%$ ) is observed for both viruses ${ }^{9}$. Therefore, the role of the polyomaviruses in respiratory illness is yet to be determined.

The data presented in this study contribute to a better understanding of the impact of viruses in respiratory infections in the infancy emphasizing the need for a more accurate diagnosis particularly for the emerging respiratory viruses.

\section{RESUMO}

\section{Infecções respiratórias agudas causadas por vírus em crianças do Rio de Janeiro e de Teresópolis, Brasil}

Neste estudo foi investigada a frequência de patógenos virais causando infecção em crianças nas cidades do Rio de Janeiro e Teresópolis. Foram coletados 205 swabs nasais de crianças com infecção aguda do trato respiratório no período de março de 2006 a outubro de 2007. Os espécimes foram testados para detecção de vírus através de (RT)-PCR e/ou PCR em tempo real. Dentre as 205 amostras testadas, 64 $(31,2 \%)$ foram positivas para pelo menos um vírus. Infecções causadas por um único agente viral foram detectadas em 56 amostras, 50 das quais eram causadas por vírus de RNA: 33 amostras foram positivas para rinovírus, cinco amostras foram positivas para influenza A, cinco amostras foram positivas para metapneumovírus, quatro amostras foram positivas para coronavírus e três amostras foram positivas para vírus respiratório sincicial. Para os vírus de DNA foram detectadas cinco amostras positivas para bocavírus humano e uma amostra positiva para adenovírus. Foram identificados oito casos de co-infecção. Nossos dados demonstram frequência elevada de infecções respiratórias virais, enfatizando a necessidade de um diagnóstico mais acurado destes patógenos, principalmente os vírus considerados emergentes. $\mathrm{O}$ fato de alguns vírus respiratórios emergentes terem sido detectados em $9,2 \%$ das amostras testadas sugere que estes vírus podem ser patógenos respiratórios importantes no país.

\section{ACKNOWLEDGMENTS}

We thank Soluza dos Santos Gonçalves for the technical assistance.

This manuscript represents part portion of a thesis submitted by M. C. M. A. to the Universidade Federal do Rio de Janeiro, Brazil, as a partial fulfillment of the requirements for a Doctor of Science degree.

This study was supported in part by Conselho Nacional de Desenvolvimento Científico e Tenológico (CNPq), Coordenação de Aperfeiçoamento de Pessoal de Nível Superior (CAPES) and by Fundação Carlos Chagas de Amparo a Pesquisa do Estado do Rio de Janeiro (FAPERJ).

\section{CONFLICT OF INTEREST}

The authors of this work have no financial or personal relationship with other people or organization that could inappropriately influence their work during the submission process.

\section{STATEMENTS OF THE AUTHORS' CONTRIBUTION}

MCMA and NS conceived and designed the study and analyzed the data. MCMA was responsible for data and sample collection, PCR analyzed and wrote the paper; NS and RBV revised the manuscript. The final manuscript has been seen and approved by all the authors.

\section{REFERENCES}

1. Aguilar JC, Pérez-Breña MP, García ML, Cruz N, Erdman DD, Echevarría JE. Detection and identification of human parainfluenza viruses 1,2,3, and 4 in clinical samples of pediatric patients by multiplex reverse transcription-PCR. J Clin Microbiol. 2000;38:1191-5

2. Albuquerque MCM, da Silva FM, Soares CC, Volotão EM, Santos N. Adenoviruses isolated from civilian and military personnel in the city of Rio de Janeiro, Brazil. Rev Inst Med Trop São Paulo. 2003;45:233-6.

3. Allander T, Andreasson K, Gupta S, Bjerkner A, Bogdanovic G, Persson MAA, et al. Identification of a third human polyomavirus. J Virol. 2007;81:4130-6.

4. Allard A, Albinsson B, Wadell G. Rapid typing of human adenoviruses by a general PCR combined with restriction endonuclease analysis. J Clin Microbiol. 2001;39:498-505.

5. Arruda E, Hayden FG, McAuliff JF, de Souza MA, Mota SB, McAuliffe MI, et al. Acute respiratory viral infections in ambulatory children of urban northeast Brazil. J Infect Dis. $1991 ; 164: 252-8$.

6. Bellei N, Carraro E, Perosa AH, Benfica D, Granato CF. Influenza and rhinovirus infections among health-care workers. Respirology. 2007;12:100-3.

7. Bezerra PG, Britto MC, Correia JB, Duarte M do C, Fonceca AM, Rose K, et al. Viral and atypical bacterial detection in acute respiratory infection in children under five years. PLoS One. 2011;6:e18928.

8. Bonfim CM, Nogueira ML, Simas PV, Gardinassi LG, Durigon EL, Rahal P, et al. Frequent respiratory pathogens of respiratory tract infections in children attending daycare centers. J Pediatr (Rio J). 2011; 87:439-44.

9. Bialasiewicz S, Whiley DM, Lambert S, Jacob K, Bletchly C, Wang D et al. Presence of the newly discovered human polyomaviruses KI and WU in Australian patients with acute respiratory tract infection. J Clin Virol. 2008;41:63-8.

10. Cabeça TK, Bellei N. Human coronavirus NL-63 infection in a Brazilian patient suspected of H1N1 2009 influenza infection: description of a fatal case. J Clin Virol. 2012;53:82-

11. Cabello C, Manjarrez ME, Olvera R, Villalba J, Valle L, Paramo I. Frequency of viruses associated with acute respiratory infections in children younger than five years of age at a locality of Mexico City. Mem Inst Oswaldo Cruz. 2006;101:21-4

12. Calvo C, García-García ML, Blanco C, Pozo F, Flecha IC, Pérez-Breña P. Role of rhinovirus in hospitalized infants with respiratory tract infections in Spain. Pediatr Infect Dis J. 2007;26:904-8.

13. Canducci F, Debiaggi M, Sampaolo M, Marinozzi MC, Berrè S, Terulla C, et al. Twoyear prospective study of single infections and co-infections by respiratory syncytial vírus and viruses indentified recently in infants with acute respiratory disease. J Med Virol. 2008;80:716-23. 

54(5): 249-55, 2012.

14. Costa LF, Yokosawa J, Mantese OC, Oliveira TFM, Silveira HL, Nepomuceno LL, et al. Respiratory viruses in children younger than five years old with acute respiratory disease from 2001 to 2004 in Uberlândia, MG, Brasil. Mem Inst Oswaldo Cruz. 2006;101:301-6

15. Costa MFL. Fatores associados à vacinação contra gripe em idoso na região metropolitana de Belo Horizonte. Rev Saúde Pública. 2008;42:100-7.

16. Cuevas LE, Ben Nassar MK, Dove W, Gurgel RQ, Greensill J, Hart CA. Human metapneumovirus and respiratory syncytial virus, Brazil. Emerg Infect Dis. 2003;9:1626-8

17. da Silva LHA, Spilki FR, Riccetto AGL, de Almeida RS, Bacarat ECE, Arns CW. Variant isolates of human metapneumovirus subgroup B genotype 1 in Campinas, Brazil. J Clin Virol. 2008:42:78-81.

18. Dare RK, Fry AM, Chittaganpitch M, Sawanpanyalert P, Olsen SJ, Erdman DD. Human coronavirus infections in rural Thailand: a comprehensive study using real-time reverse-transcription polymerase chain reaction assay. J Infect Dis. 2007;196:1321-8.

19. Debur MC, Vidal LR, Stroparo E, Nogueira MB, Almeida SM, Takahashi GA, et al. Impact of human metapneumovirus infection on in and outpatients for the years 2006-2008 in Southern Brazil. Mem Inst Oswaldo Cruz. 2010;105:1010-8.

20. do Carmo Debur MC, Bordignon J, Duarte dos Santos CN, Vidal LR, Nogueira MB, de Almeida SM, et al. Acute respiratory infection by human metapneumovirus in children in southern Brazil. J Clin Virol. 2007;39:59-62.

21. Donaldson GC. Climate change and the end of the respiratory syncytial virus season. Clin Infect Dis. 2006;42:677-9.

22. Donalisio MR, Ruiz T, Cordeiro R. Factors associated with influenza vaccination among elderly persons in southeast Brazil. Rev Saúde Pública. 2006;40:115-9.

23. Esper F, Weibel C, Ferguson D, Landry ML, Kahn JS. Coronavirus HKU1 infection in the United States. Emerg Infect Dis. 2006;12:775-9.

24. Farha T, Thomson AH. The burden of pneumonia in children in the developed world. Pediatr Resp Rev. 2005;6:76-82.

25. Fé MMM, Monteiro AJ, Moura FEA. Parainfluenza virus infections in a tropical city: clinical and epidemiological aspects. Braz J Infect Dis. 2008;12:192-7.

26. Francisco PM, Donalisio MR, Barros MB, César CL, Carandina L, Goldbaum M. Fatores associados à vacinação contra a influenza em idosos. Rev Panam Salud Publica. $2006: 19 \cdot 259-64$

27. Gagliardi TB, Iwamoto MA, Paula FE, Proença-Modena JL, Saranzo AM, Criado MF, et al. Human bocavirus respiratory infections in children. Epidemiol Infect. 2009;137:1032-5.

28. Gaynor AM, Nissen MD, Whiley DM, Mackay IM, Lambert SB, Wu G, et al. Identification of a novel polyomavirus from patients with acute respiratory tract infections. PLoS Pathog. 2007;3:e64.

29. Goes LG, Durigon EL, Campos AA, Hein N, Passos SD, Jerez JA. Coronavirus HKU1 in children, Brazil, 1995. Emerg Infect Dis. 2011;17:1147-8.

30. Kahn JS. Newly discovered respiratory viruses: significance and implications. Curr Opin Pharmacol. 2007; 7:478-83.

31. Khetsuriani N, Lu X, Teague WG, Kazerouni N, Anderson LJ, Erdman DD. Novel human rhinoviruses and exacerbation of asthma in children. Emerg Infect Dis. 2008;14:1793-

32. Mackay IM, Jacob KC, Woolhouse D, Waller K, Syrmis MW, Whiley DM, et al. Molecular assays for detection of human metapneumovirus. J Clin Microbiol. 2003;41:100-5.
33. Miyao CR, Gilio AE, Vieira S, Hein N, Pahl MMC, Betta SL, et al. Infecções virais em crianças internadas por doença aguda do trato respiratório inferior. J Pediatr (Rio J). 1999;75:334-44

34. Myatt TA, Johnston SL, Rudnick S, Milton DK. Airborne rhinovirus detection and effect of ultraviolet irradiation on detection by a semi-nested RT-PCR assay. BMC Public Health. 2003,3:5

35. Nascimento JP, Siqueira MM, Sutmoller F, Krawczuk MM, Farias V, Ferreira V, et al Longitudinal study of acute respiratory diseases in Rio de Janeiro: occurrence of respiratory viruses during four consecutive years. Rev Inst Med Trop São Paulo. 1991;33:287-96

36. Nascimento-Carvalho CM, Ribeiro CT, Cardoso MR, Barral A, Araújo-Neto CA, Oliveira $\mathrm{JR}$, et al. The role of respiratory viral infections among children hospitalized for community-acquired pneumonia in a developing country. Pediatr Infect Dis J. 2008;27:939-41.

37. Nascimento MS, Souza AV, Ferreira AV, Rodrigues JC, Abramovici S, Silva Filho LV. High rate of viral identification and coinfections in infants with acute bronchiolitis. Clinics (Sao Paulo). 2010;65:1133-7.

38. Oliveira R, Machado A, Tateno A, Boas LV, Pannuti C, Machado C. Frequency of human metapneumovirus infection in hematopoietic SCT recipients during 3 consecutive years. Bone Marrow Transplant. 2008;42:265-9.

39. Oliveira TFM, Freitas GRO, Ribeiro LZG, Yokosawa J, Siqueira MM, Portes SAR, et al. Prevalence and clinical aspects of respiratory syncytial vírus A and B groups in children seen at Hospital de Clínicas of Uberlândia, MG, Brazil. Mem Inst Oswaldo Cruz. 2008;103;417-22

40. Pilger DA, Cantarelli VV, Amantea SL, Leistner-Segal S. Detection of human bocavirus and human metapneumovirus by real-time PCR from patients with respiratory symptoms in Southern Brazil. Mem Inst Oswaldo Cruz. 2011;106:56-60.

41. Pyrc K, Berkhout B, van der Hoek L. The novel human coronaviruses NL63 and HKU1. J Virol. 2007;81:3051-7.

42. Salomão Junior JB, Gardinassi LG, Simas PV, Bittar CO, Souza FP, Rahal P, et al. Human respiratory syncytial virus in children hospitalized for acute lower respiratory infection. J Pediatr (Rio J). 2011; 87:219-24.

43. Serafino RL, Gurgel RQ, Dove W, Hart CA, Cuevas LE. Respiratory syncytial virus and metapneumovirus in children over two seasons with a high incidence of respiratory infections in Brazil. Ann Trop Pediatr. 2004;24:213-7.

44. Silva MJ, Ferraz C, Pissarra S, Cardoso MJ, Simões J, Vítor AB. Role of viruses and atypical bacteria in asthma exacerbations among children in Oporto (Portugal) Allergol Immunopathol (Madr). 2007;35:4-9.

45. Sloots TP, McErlean P, Speicher DJ, Arden KE, Nissen MD, Mackay IM. Evidence of human coronavirus HKU1 and human bocavirus in Australian children. J Clin Virol. 2006;35:99-102.

46. Sloots TP, Whiley DM, Lambert SB, Nissen MD. Emerging respiratory agents: new viruses for old diseases? J Clin Virol. 2008;42:233-43.

47. Souza LS, Ramos EA, Carvalho FM, Guedes VM, Souza LS, Rocha CM, et al. Viral respiratory infections in young children attending day care in urban Northeast Brazil. Pediatr Pulmonol. 2003;35:184-91.

48. Stockton J, Ellis JS, Saville M, Clewley JP, Zambon MC. Multiplex PCR for typing and subtyping influenza and respiratory syncytial viruses. J Clin Microbiol. 1998;36:29905 .

49. Straliotto SM, Siqueira MM, Machado V, Maia TMR. Respiratory viruses in the pediatric intensive care unit: prevalence and clinical aspects. Mem Inst Oswaldo Cruz. 2004;99:883-7. 

54(5): 249-55, 2012.

50. Straliotto SM, Siqueira MM, Muller RL, Fischer GB, Cunha MLT, Nestor SM. Viral etiology of acute respiratory infections among children in Porto Alegre, RS, Brazil. Rev Soc Bras Med Trop. 2002;35:283-91.

51. Thomazelli LM, Vieira S, Lea AL, Sousa TS, Oliveira DBL, Golono MA, et al. Surveillance of eight respiratory viruses in clinical samples of pediatric patients in southeast Brazil. J Pediatr (Rio J). 2007;83:422-8.

52. Treanor JJ. Respiratory infections. In: Richman DD, Whitley RJ, Hayden FG, editors Clinical Virology. $3^{\text {rd }}$ ed. Washington: ASM Press: 2009. p. 7-27.

53. Tsuchiya LRRV, Costa LMD, Raboni SM, Nogueira MB, Pereira LA, Rotta I, et al. Viral respiratory infection in Curitiba, southern Brazil. J Infect. 2005;51:401-7.

54. Turner RB, Lee WM. Rhinovirus. In: Richman DD, Whitley RJ, Hayden FG, editors. Clinical Virology. $3^{\text {rd }}$ ed. Washington: ASM Press; 2009. p. 1063-82.

55. Turner RB. Rhinovirus: more than just a common cold virus. J Infect Dis. 2007;195:765-6.

56. van der Zalm MM, Rossen JWA, van Ewijk BE, Wilbrink B, van Esch PCHM, Wolfs TFW, et al. Prevalence and pathogenicity of WU and KI polyomaviruses in children, the Netherland. Emerg Infect Dis. 2008;14:1787-9.

57. van Elden LJ, van Loon AM, van Alphen F, Hendriksen KA, Hoepelman AI, van Kraaij MG, et al. Frequent detection of human coronaviruses in clinical specimens from patients with respiratory tract infection by use of a novel real-time reversetranscriptase polymerase chain reaction. J Infect Dis. 2004;189:652-7.
58. Vidal LRR, Siqueira MM, Nogueira MB, Raboni SM, Pereira LA, Takahashi GRA, et $a l$. The epidemiology and antigenic characterization of influenza viruses isolated in Curitiba, south Brazil. Mem Inst Oswaldo Cruz. 2008;103:180-5

59. Watanabe AS, Carraro E, Candeias JM, Donalísio MR, Leal E, Granato CF, et al. Viral etiology among the elderly presenting acute respiratory infection during the influenza season. Rev Soc Bras Med Trop. 2011;44:18-21.

60. Watanabe AS, Carraro E, Moreira L, Camargo C, Sinohara J, Puerari D, et al. Respiratory virus infections among hospitalized patients with suspected influenza A H1N1 2009 virus during the first pandemic wave in Brazil. Braz J Infect Dis. 2011;15:220-4

61. Williams JV, Piedra PA, Englund JA. Respiratory syncytial virus, human metapneumovirus, and parainfluenza viruses. In: Richman DD, Whitley RJ, Hayden FG, editors. Clinical Virology. $3^{\text {rd }}$ ed. Washington: ASM Press; 2009. p. 817-47.

62. Woo PCY, Lau SKP, Tsoi HW, Huang Y, Poon RWS, Chu CM, et al. Clinical and molecular epidemiological features of coronavirus HKU1-associated community-acquired pneumonia. J Infect Dis. 2005;192:1898-907.

Received: 27 February 2012

Accepted: 31 May 2012 


\section{Revista do Instituto de Medicina Tropical de São Paulo on line.}

Publications from 1987 to the present data are now available on:

http://www.scielo.br/rimtsp

PAST ISSUES 1959-1989 (PDF)

www.imt.usp.br/portal/

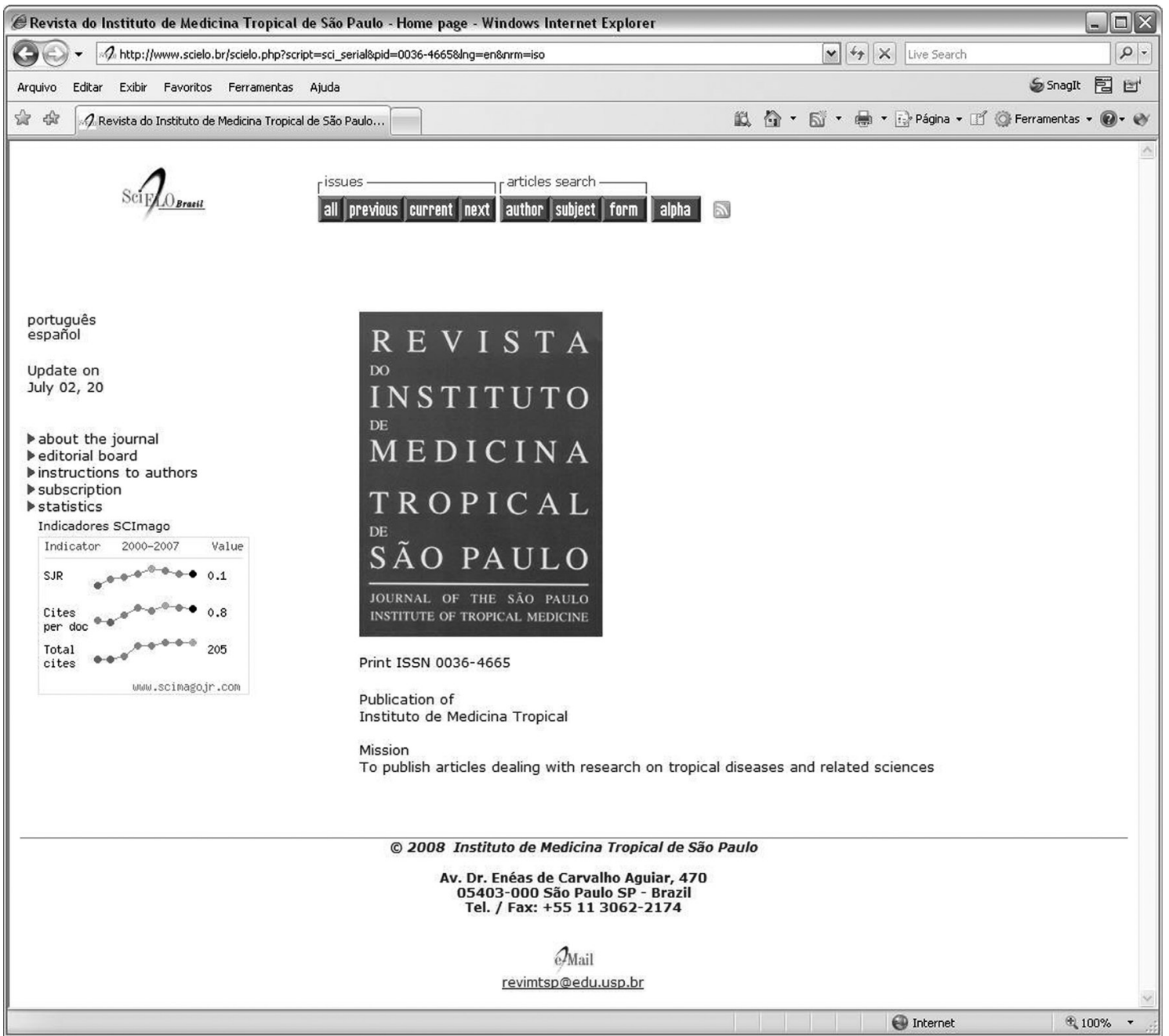

SciELO - The Scientific Electronic Library OnLine - SciELO is an electronic virtual covering a selected collection of Brazilian scientific journals.

The library is an integral part of a project being developed by FAPESP - Fundação de Amparo à Pesquisa do Estado de São Paulo, in partnership with BIREME - the Latin American and Caribbean Center on Health Sciences Information.

SciELO interface provides access to its serials collection via an alphabetic list of titles or a subject index or a search by word of serial titles, publisher names, city of publication and subject.

The interface also provides access to the full text of articles via author index or subject index or a search form on article elements such as author names, words from title, subject and words from full text.

FAPESP/BIREME Project on Scientific Electronic Publications Latin American and Caribbean Center on Health Sciences Information

Rua Botucatu 862 - 04023-901 São Paulo, SP - Brazil

Tel. (011) 5576-9863

scielo@bireme.br 